\title{
Asynchronous reproduction and multi-spawning in the coral-excavating sponge Cliona delitrix
}

\author{
ANDIA CHAVES-FONNEGRA ${ }^{1}$, MANUEL MALDONADO ${ }^{2}$, PATRICIA BLACKWELDER ${ }^{1}$ AND JOSE V. LOPEZ ${ }^{1}$ \\ ${ }^{1}$ NOVA Southeastern University, Oceanographic Center, 8000 North Ocean Drive. Dania Beach, FL 33004, USA, ${ }^{2}$ Department of \\ Aquatic Ecology, Center for Advanced Studies of Blanes (CEAB-CSIC), Acceso Cala St. Francesc 14, Blanes, 17300 Girona, Spain
}

\begin{abstract}
Cliona delitrix is one of the most abundant and destructive coral-excavating sponges on Caribbean reefs. However, basic aspects of its reproductive biology, which largely determine the species propagation potential, remain unknown. A 2-year study (October 2009 to September 2011) was conducted to determine the reproductive cycle and gametogenesis of a C. delitrix population located in a shallow reef in Florida, USA. Mesohyl tissue collected from randomly chosen and tagged sponge individuals was sampled one to several times a month, and analysed by light and transmission electron microscopy (TEM). Cliona delitrix is oviparous and gonochoric, except for a few simultaneous hermaphroditic individuals. The C. delitrix reproductive cycle in Florida is from April to December, and is triggered by an increase in seawater temperature to $25^{\circ} \mathrm{C}$. Oogenesis and spermatogenesis were asynchronous among individuals; with different cohorts of oocytes co-occurring in females, and spermatic cysts in males. Granulose cells acted as nurse cells, contributing to the growth and maturation of both female and male gametes. Spawning of gametes was not always synchronized with full moon phase. Unlike most other oviparous sponges, the reproductive cycle of C. delitrix is versatile and includes multiple spawning events during the summer of each year. This characteristic maximizes sponge propagation on coral reefs during the warmer months of the year, particularly when thermal stress induces coral mortality. This aspect, combined with its success on polluted areas, make C. delitrix a suitable bioindicator of coral reef health.
\end{abstract}

Keywords: Reproductive biology, life cycle, gametogenesis, bioindicator, Florida, Caribbean Sea

Submitted 9 December 2014; accepted 14 April 2015

\section{INTRDDUCTION}

Excavating sponges are becoming more prevalent on coral reefs (e.g. Holmes, 1997; Schönberg, 2001; Rützler, 2002; Ward-Paige et al., 2005; Schönberg \& Ortiz, 2008; Carballo et al., 2013). They spread faster in warmer temperatures (Cortés et al., 1984; Rützler, 2002; Weil, 2002; Carballo et al., 2013), and increase their boring rates at lower $\mathrm{pH}$ (Wisshak et al., 2012; Duckworth \& Peterson, 2013; Fang et al., 2013; Enochs et al., 2015); abilities that can make them strong competitors during expected climate change scenarios (Carballo et al., 2013; Fang et al., 2013; Wisshak et al., 2014; Enochs et al., 2015). However, the reproductive strategies and propagation mechanisms of most coralexcavating sponges are unknown or vague (González-Rivero et al., 2013). This is the case for Cliona delitrix Pang (1973) (Hadromerida, Demospongiae), one of the most destructive species to Caribbean coral reefs; it excavates $10-12 \mathrm{~cm}$ deep cavities inside coral skeletons, or deeper (Pang, 1973; Zilberberg et al., 2006; Chaves-Fonnegra \& Zea, 2007), and spreads laterally at mean rates of $\sim 1.5 \mathrm{~cm} \mathrm{y}^{-1}$ (Figure 1), eroding massive live corals (Pang, 1973; Rützler, 2002;

Corresponding author:

A. Chaves-Fonnegra

Email: andiachaves@gmail.com
Chaves-Fonnegra \& Zea, 2007, 2011). Zilberberg et al. (2006) and Chaves-Fonnegra et al. (2015) suggested C. delitrix propagation is sexually through larvae, but its reproductive cycle and larvae are unknown.

An evaluation of environmental conditions, favourable for the propagation of excavating sponges, is required to understand their present and possible future ecological impacts under climate change. Therefore, a fundamental step is to determine the reproductive biology of excavating sponges, which except for a few cases, remains poorly understood to date. The sexual reproductive cycle of Cliona and Pione excavating sponges has been described in five species: Cliona c.f. celata Grant (1826) and C. viridis Schmidt (1862) (Piscitelli et al., 2011); Pione truitti Old (1941) (Pomponi \& Meritt, 1990); C. tenuis Zea \& Weil (2003) (González-Rivero et al., 2013) and C. Vermifera Hancock (1867) (Bautista-Guerrero et al., 2014). Annual changes in temperature represent the main environmental variable influencing their oogenesis and spermatogenesis.

Cliona and Pione species can be hermaphrodites or gonochoric, and are mostly oviparous (Nassonov, 1883; Lévi, 1956; Pomponi \& Meritt, 1990; Maldonado \& Riesgo, 2008; Piscitelli et al., 2011). However, their oocytes can be fertilized internally before expulsion into the water column, whereas embryogenesis is external (Nassonov, 1883; BautistaGuerrero et al., 2014). Viviparity has only been reported in temperate Cliona lobata Hancock (1849) (Topsent, 1900). In 


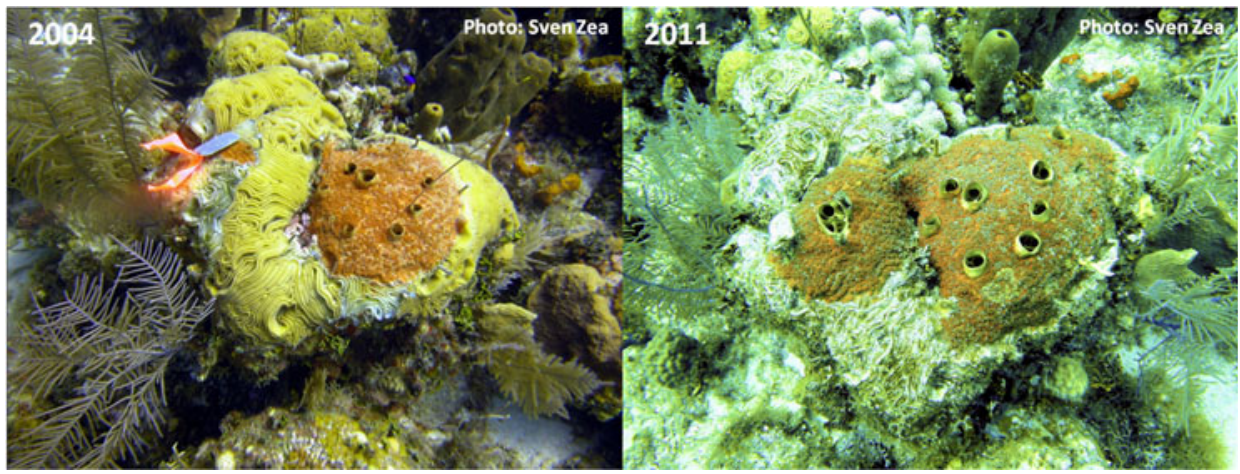

Fig. 1. Excavating sponge Cliona delitrix on coral Diploria labyrinthiformis in San Andrés Island, Colombia. Photographs were taken in 2004, and 7 years after, in 2011. The coral (yellow) died, and the sponge (orange) grew on most of the coral colony. Photos courtesy of S. Zea.

general, for both oviparous and viviparous sponges late-stage oocytes are surrounded by a layer of parent cells, also called 'nurse cells or granular cells' (Warburton, 1961; Maldonado, 2009; Maldonado \& Riesgo, 2009; Piscitelli et al., 2011). Eggs are released, and embryonic development leads to a freeswimming larval stage (Maldonado \& Bergquist, 2002; Maldonado \& Riesgo, 2009). Characterizing the spermatogenesis in oviparous sponges can be difficult because of its short time span, lasting only days to weeks (Maldonado \& Riesgo, 2008). Therefore, investigation of spermatogenesis in the genus Cliona remains incomplete. Also, collecting fertilized eggs and larvae remains difficult, contributing to the lack of knowledge of embryonic development in oviparous Cliona.

The study of reproductive cycles and gametogenesis in coral-excavating sponges will aid in the understanding of how sponges disseminate and contribute to coral mortality and bioerosion, how human activities and climate change may impact coral reefs and the distribution of these sponges (Rützler, 2002; Ward-Paige et al., 2005; Schönberg \& Ortiz, 2008), and to improve monitoring efforts and coral restoration initiatives (e.g. Lang, 2003; Gilliam, 2012). With these potential outcomes in mind, this study aims to determine the sexual reproductive cycle and gametogenesis in the coral-excavating sponge $C$. delitrix. Two hypotheses were proposed: (1) C. delitrix is an oviparous, hermaphroditic sponge similar to most other members of the genus Cliona; (2) this species has synchronous female and male gamete maturation leading to a single spawning pulse over one year, similar to most other members of the genus Cliona.

\section{METH口DS}

\section{Study area and sampling}

Over 2 years, a population of Cliona delitrix was sampled on the inner reef of Broward County, Florida, USA $\left(26^{\circ} 08^{\prime} 31.8^{\prime \prime} \mathrm{N} 80^{\circ} 05^{\prime} 47.64^{\prime \prime} \mathrm{W}\right)$ at a depth of $18-22 \mathrm{~m}$. For a more detailed description of the area see Banks et al. (2008). During scuba dives, a $3 \mathrm{~cm}$ diameter steel corer and a hammer were used to extract sponge tissue samples $(1 \mathrm{~cm}$ thick) from coral skeletons. During the first year (October 2009 to September 2010), samples were collected both from four tagged individuals once a month and from 5-10 randomly located individuals once or twice a month, depending on how intense reproductive activity was inferred in the preceding sampling. During the second year (October 2010 to
September 2011), 10 tagged individuals were sampled once a month, except in May, June, August and September when samples were collected two to four times. Additionally, we randomly sampled 5-10 individuals from April to September one to four times per month. Tagged and un-tagged individuals were selected haphazardly. To evaluate if environmental variables influenced sponge reproduction, temperature was recorded during the 2 years, and every $2 \mathrm{~h}$ from two HOBO temperature loggers placed on the reef at $25 \mathrm{~m}$ depth $\left(26^{\circ} 08^{\prime} 52.32^{\prime \prime} \mathrm{N} 80^{\circ} 05^{\prime} 45.48^{\prime \prime} \mathrm{W}\right)$ by the South East Florida Coral Reef Monitoring Project (SECREMP) (Gilliam, 2012). Also, data on moon phases were obtained from the US Naval observatory for each year (http://aa.usno. navy.mil/data/docs/MoonFraction.php).

\section{Histology and light microscopy}

Immediately after collection, all sponge tissue samples were transported in ambient seawater to the laboratory and fixed for histology in Bouin's fixative solution for 2 days. Samples were then rinsed in distilled water twice for $15 \mathrm{~min}$ and decalcified using a $10 \%$ solution of $\mathrm{HCl} / \mathrm{EDTA}$ for 3 days (modified from Renegar et al., 2008). After decalcification, samples were rinsed with three successive changes of distilled water (20 min each) and placed separately in 50\% ethanol inside $50 \mathrm{~mL}$ Falcon tubes for at least $1 \mathrm{~h}$. To further dehydrate tissue, samples were placed in $70 \%$ ethanol for $1 \mathrm{~h}$, and then desilicified in $4 \%$ hydrofluoric acid overnight at $4{ }^{\circ} \mathrm{C}$ to remove spicules. After approximately $24 \mathrm{~h}$ samples were rinsed in $70 \%$ ethanol for $20 \mathrm{~min}$, and then placed inside histology cassettes and rinsed twice in $95 \%$ ethanol for $15 \mathrm{~min}$ each, and in two changes of $100 \%$ for 10 min. Fragments inside cassettes were submerged in xylene for two changes of $15 \mathrm{~min}$ each, and placed in two changes of paraffin in the oven at $60^{\circ} \mathrm{C}$ for $15 \mathrm{~min}$ each. Samples were then transferred to fresh paraffin, using a Sakura Tissue-Tek embedding centre at the Nova Southeastern University (NSU)-Oceanographic Center Coral Histology Lab. The paraffin blocks were placed on a cold plate (Tissue-Tek 4650) to remove moulds, and kept in the refrigerator at $4{ }^{\circ} \mathrm{C}$ in fresh water until sectioning. Sections $4 \mu \mathrm{m}$ thick were obtained on a Leica RM2125 microtome. Three sections per sample were made, each separated by $1000 \mu \mathrm{m}$, and each was placed on a different slide. All sections were stained with Heidenhain's, and some with haematoxylineosin for comparison (staining procedures in ChavesFonnegra, 2014). Although Heidenhain's is a common stain 
for corals it is less commonly used for sponges, but it provided a good resolution of sponge structures such as cell nuclei (dark red), collagen and choanocytes (blue) and granulose cells (yellow).

To estimate gamete density over time, two photographs $(100 \times)$ of each of the three sections per individual were taken. Photographs were taken at least $210 \mu \mathrm{m}$ apart to avoid overlapping areas and density overestimation. The area of suitable tissue varied among sections due to the 'porosity' of the tissue and the holes left by the $\mathrm{HCl}$-digested coral calcium carbonate. Thus, to obtain equivalent areas of tissue per picture, all pictures were contrasted on a white background using the program Corel Paintshop Pro $\mathrm{X}_{4}$, and a Matlab code was written to calculate the percentage of tissue (Chaves-Fonnegra, 2014).

Digital histological images were analysed to measure and count gametes and to study cytology. To compare different individuals, the number of reproductive structures of interest (i.e. gametes) were assessed from an area of $1 \mathrm{~mm}^{2}$ in each photograph. Thus, the total tissue area microscopically sampled for each individual was the sum of the area of the six pictures taken $\left(6 \mathrm{~mm}^{2}\right)$. The number of oocytes per $\mathrm{mm}^{3}$ (O) of tissue was estimated applying the formula proposed by Elvin (1976) and used for sponge gametes estimations by Maldonado \& Riesgo (2009):

$$
O=(N \cdot(t /(d+t))) \cdot F
$$

Where $O$ is the number of oocytes or spermatocytes per $\mathrm{mm}^{3}$ of tissue, $N$ is the number of oocytes or spermatocytes counted in the histological sections per individual (in this case $6 \mathrm{~mm}^{2}$ ); $t$ is the thickness of section $(4 \mu \mathrm{m}), d$ is the average diameter of oocytes for each month and $F(=41.67)$ is the factor to convert the volume of the observation to $1 \mathrm{~mm}^{3}$.

To describe the reproductive cycle and examine the potential relationship between gametogenesis and seawater temperature, we plotted the monthly density and percentages of oocyte and spermatocyte (number of structures $\mathrm{mm}^{-3}$ ) vs monthly average temperature. To calculate the diameter of reproductive structures, pictures of up to 15 reproductive structures (eggs, sperm or transdifferentiated choanocytes) were taken in each individual, and measured using the Image J program (http://rsbweb.nih.gov/ij/index.html). Also, Pearson or Spearman correlations (depending on the normal distribution of the values) were used to test if the density of reproductive structures correlated with seawater temperature. To avoid confusion in the text, oocyte development is referred to as stages I-IV, whereas spermatic cysts development as cysts $1-4$.

\section{Electron microscopy}

Subsamples from the sponges were fixed for transmission electron microscopy (TEM) in $2 \%$ glutaraldehyde and $0.05 \mathrm{M}$ sodium cacodylate buffer prepared in filtered seawater to maintain osmolarity, following the protocol by Miller et al. (2011). Only those samples corroborated by the light microscopy study to contain reproductive elements were further processed for TEM. After the primary fixation, subsamples were rinsed three times for 10 min each in $0.05 \mathrm{M}$ sodium cacodylate buffer. Then, they were transferred to a second fixative solution of $1 \%$ osmium tetroxide in buffer for $45 \mathrm{~min}$, followed by three 10-min rinses in the $0.05 \mathrm{M}$ sodium cacodylate buffer. Samples were dehydrated in a graded series of ethanol at $20,40,60,70,90$ and $100 \%$, three changes of 5 min each.

Following dehydration, samples were placed in Spurr resin, which was changed three times over a period of $3 \mathrm{~h}$. Samples were then placed in flat embedding moulds and polymerized overnight at $60^{\circ} \mathrm{C}$ in a stable temperature oven. Blocks were trimmed using GEM/STAR single edge razors to expose the area of tissue of interest. Blocks were then sectioned to $90 \mathrm{~nm}$ in a Porter Blum MT-2 Ultramicrotome fitted with a diamond knife. To obtain membrane contrast, sections were placed on copper grids and stained with lead citrate (6 min) and uranyl acetate (10 min). Sections stained with lead citrate and/or uranyl acetate, and non-stained sections were observed in a Philips 300 TEM at the NSU Oceanographic Center, and electron micrographs taken with a JEOL JEM 1400 X at the Miller School of Medicine at the University of Miami.

\section{RESULTS}

\section{Gametogenesis}

Developing oocytes (stages I and II, Table 1, Figure 2) were found in Cliona delitrix tissue in all sampled months for both years, except April 2010 (Figure 3), but matured (stages III and IV, Table 1, Figure 2) only within the period from April-May to November-December, depending on year (Figures 3 \& 4). When the smallest recognizable oocytes appeared, choanocyte chambers around them were absent or disorganized (Figure $2 \mathrm{~A}$ ). Granulose cells (nurse cells) played an important role in the maturation of oocytes; stage II and III oocytes form pseudopodia becoming amoeboid in shape, engulfing granular cells, as observed in histology and TEM micrographs (Figure $2 \mathrm{C}, \mathrm{D}, \mathrm{G}, \mathrm{H}$ ). At stage IV granular cells abundantly surrounded oocytes (Figure $2 \mathrm{E}, \mathrm{F}$ ). During the warmer months, different cohorts of oocytes

Table 1. Histological features of oogenesis stages in Cliona delitrix. Stage I: young oocytes during the first growth phase; Stage II: oocytes undergoing yolk accumulation; Stage III: oocytes about to complete yolk accumulation; stage IV: mature oocytes.

Stage I
Size: $10-45 \mu \mathrm{m}(21.7 \pm 7.3 ; \mathrm{N}=170)$; shape rounded; no accumulation of yolk granules, or some of them start to be
present
Size: $11.2-79.9 \mu \mathrm{m}(34.02 \pm 10.6 ; \mathrm{N}=1214)$; shape oval to amoeboid with pseudopodia; yolk granules, lipids and
inclusions with heterogeneous content are accumulated in the cytoplasm and granulose cells are in contact and being
engulfed by the oocyte
Size: $23.8-97.2 \mu \mathrm{m}(56.4 \pm 11.0 ; \mathrm{N}=585)$; shape rounded, although still forming pseudopodia; yolk granules and
inclusions only in peripheral cytoplasm; many granulose cells surrounding or inside the oocyte
Stage III
Stage IV $52.5-96.3 \mu \mathrm{m}(73.5 \pm 8.1 ; \mathrm{N}=117)$; shape completely round and surrounded with granular cells; space between the
mesohyl and the oocyte-granular cells is formed



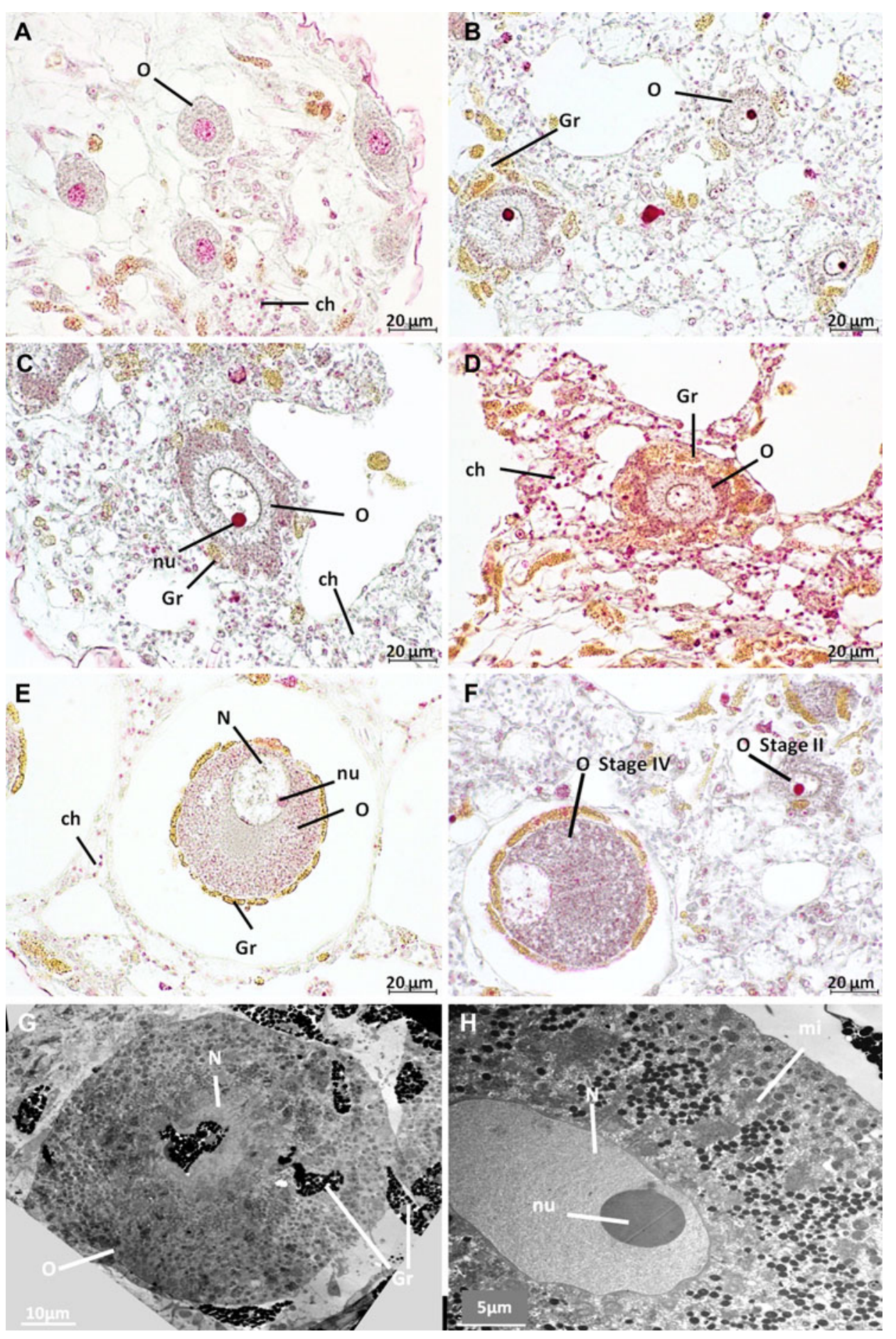

Fig. 2. Oogenesis observed by light microscopy and TEM. (A) Young oocytes during the first growth phase in stage I; (B) Oocytes in stages II and III with inclusions in the cytoplasm; (C) Oocyte in stage III with yolk only in the periphery; (D) Granulose cells inside stage III oocytes; (E) Oocyte stage IV separated from the mesohyl and completely surrounded by granulose cells. (F and G) TEM of oocytes in stage II with granulose cells and inclusions in the cytoplasm. Abbreviations, ch: choanocytes chambers; Gr: granulose cell; mi: mitochondria; N: nucleus; nu: nucleolus; O: oocyte.

were observed to co-occur in the same female individual (Figures $2 \mathrm{~F} \& 5$ ). These results suggested that the oogenesis of C. delitrix was asynchronous at the individual level. During summer time, oocytes can mature relatively rapidly, varying between 2 weeks and a month (Figure 5, female 4). However, a female individual did not necessarily produce oocytes every month (Figure 5). Also, the same female individual could produce gametes during most of the reproductive cycle (April-December), showing one or two peaks of higher density, while a few females maintained oocytes all year round (Figure 5). Neither embryos nor larvae were observed in any individual.

Transdifferentiated choanocytes (i.e. the precursor spermatogonial cells, Figure 6A, B) were found in most of the sampled dates during the warmer months, but spermatic cysts were detected only at some of the sampling dates during 

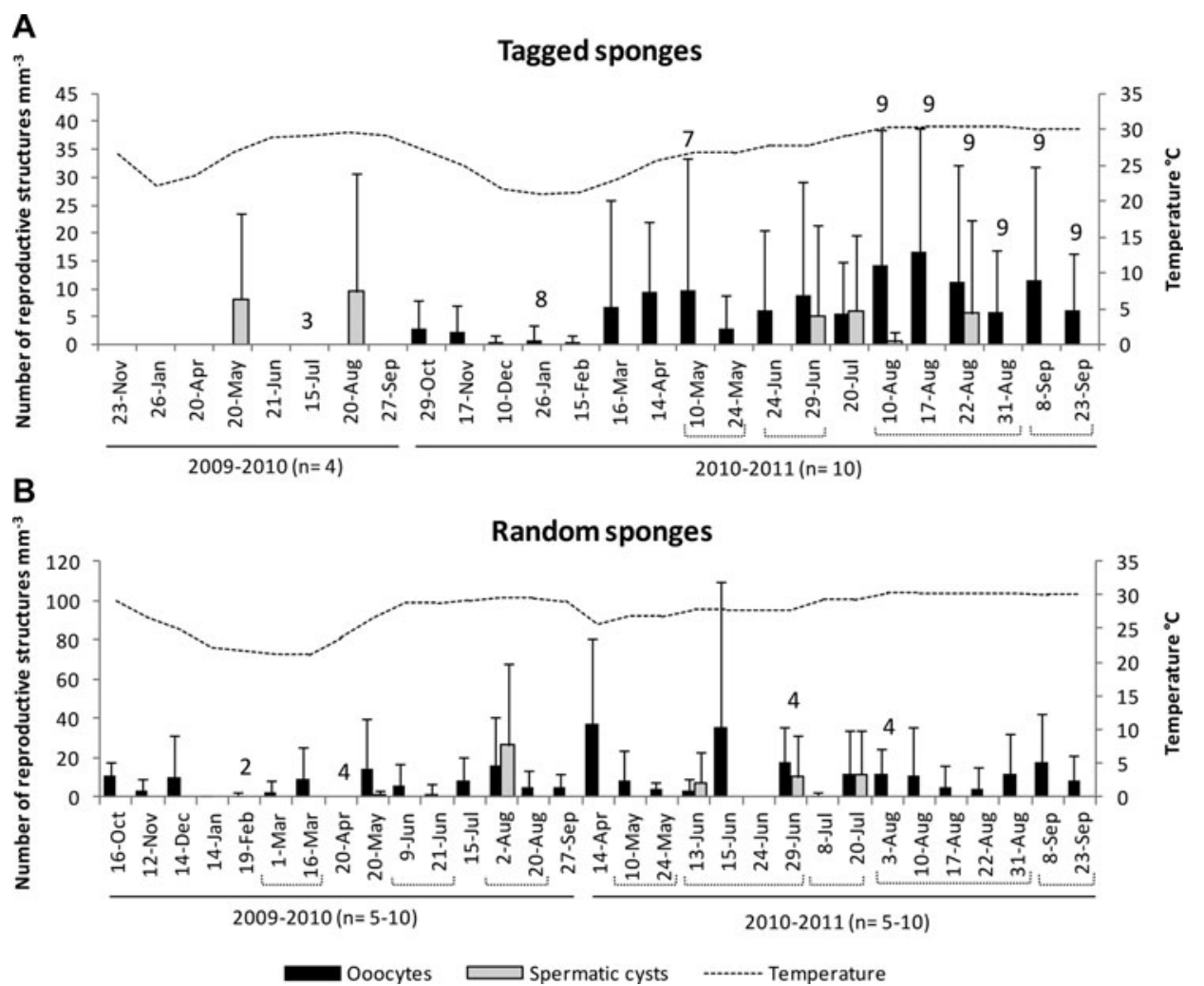

Fig. 3. Density of reproductive structures in relation to seawater temperature. Upper graph corresponds to tagged individuals, and lower graph to random individuals. Numbers on top of the bars are indicating smaller than targeted samples due to deterioration of the sponge (tagged individuals, $\mathrm{N}=4$ in year 1 and 10 in year 2), and bad weather or lack of sponges in the sampling area (random individuals, $\mathrm{N}=10$ ).
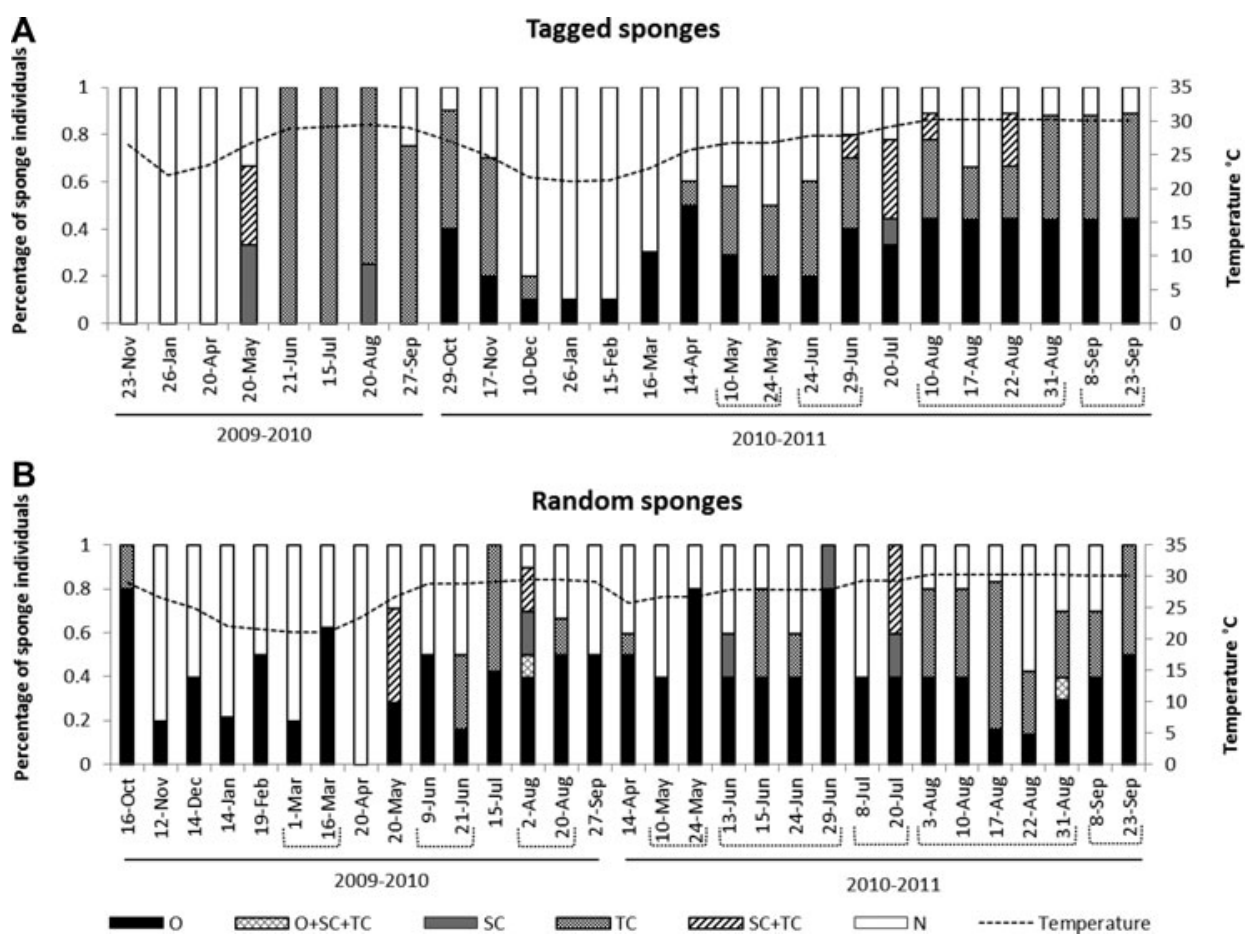

Fig. 4. Percentage of individuals containing reproductive structures in relation to seawater temperature. Upper graph correspond to tagged individuals, and bottom one to random individuals. N: none; O: oocytes; SC: spermatic cysts: TC: transdifferentiated choanocytes; SC + TC: males with both spermatic cysts and transdifferentiated choanocytes; O + SC + TC: Hermaphrodites containing oocytes, spermatic cysts and transdifferentiated choanocytes. Number of individuals collected $(\mathrm{N})$ as in Figure 3 . 


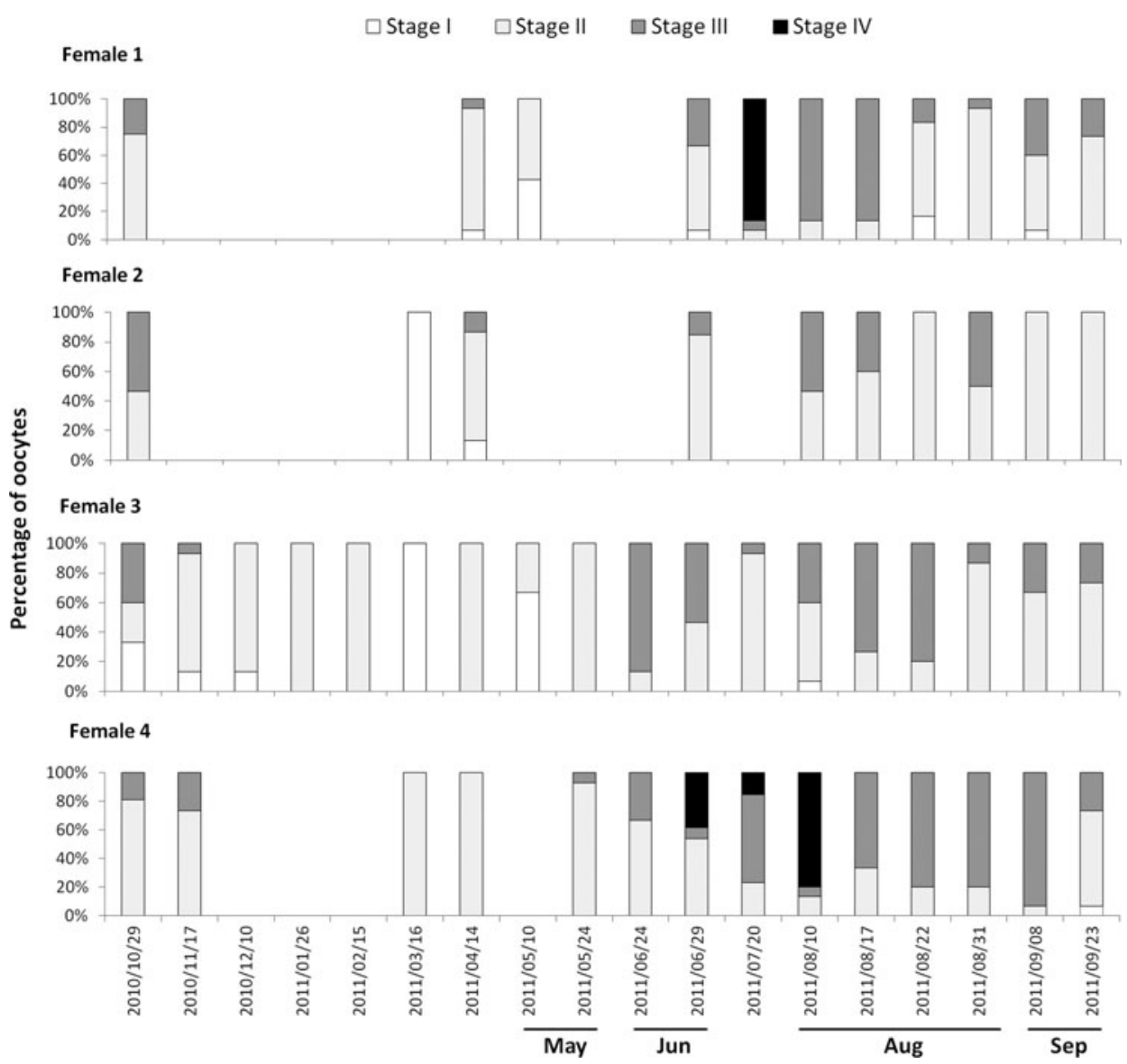

Fig. 5. Percentage of oocytes at different developmental stages for the tagged sponges that were females $(\mathrm{N}=4)$ in the sampling year $2010-2011$. The other six individuals: three were males (Figure 7) and three did not present any reproductive structure.

summer (Figures $3 \& 4$ ). The transdifferentiated choanocytes had a denser and larger nucleus $(2-2.5 \mu \mathrm{m})$ than choanocytes $(1-1.5 \mu \mathrm{m})$, two or three large vacuoles, and some small mitochondria, all having lost the typical collar of choanocytes (Figure 6G). Some other precursor cells had nuclei of similar size or slightly larger $(3 \mu \mathrm{m})$ than choanocytes showing synaptonemal complexes, which are typical of prophase I in primary spermatocytes (Figure $6 \mathrm{H}$ ). A possible flagellum was also observed in some of the primary spermatocytes (Figure 6H). Transdifferentiation was synchronous within a choanocyte chamber, with most of the choanocytes becoming spermatogonia. Transdifferentiating choanocytes aggregated and became surrounded by granulose cells, which also occurred between them (Figure 6B, C). Aggregations of transdifferentiated choanocytes were smaller than spermatic cysts $(X \pm$ $\mathrm{SE}=42.1 \pm 14.6 \mu \mathrm{m}, \mathrm{N}=598$ ).

Four different stages of development were identified in spermatic cysts (Figure 6). At stage 1 , cysts $(X \pm \mathrm{SE}=$ $61.8 \pm 13 \mu \mathrm{m}, \mathrm{N}=15)$ contained mostly spermatogonia (Figure 6C). Stage 2 cysts were larger than stage 1 cysts and possibly contained spermatocytes I $(X \pm \mathrm{SE}=82.3 \pm$ $28.1 \mu \mathrm{m}, \mathrm{N}=69$; Figure $6 \mathrm{D})$. Stage 3 cysts $(X \pm \mathrm{SE}=$ $76.6 \pm 26.7 \mu \mathrm{m}, \mathrm{N}=324)$ were almost the same average size as stage 2 cysts and probably contained spermatids or spermatozoa (Figure 6D-E); they were difficult to discriminate from each other because we failed to observe them in TEM samples and because a patent flagellum is already present in both the spermatid and the spermatozoon of demosponges
(Riesgo et al., 2007; Riesgo \& Maldonado, 2009). Stage 4 cysts were the largest stage observed $(X \pm \mathrm{SE}=109 \pm$ $34.1 \mu \mathrm{m}, \mathrm{N}=15$ ), with the head of the spermatozoa accumulated at one side of cyst and the flagella pointing in the opposite direction, likely ready for imminent spawning (Figure 6F).

Male individuals with mature spermatic cysts also simultaneously contained transdifferentiated choanocytes or spermatic cysts in earlier maturation stages. This suggested that spermatogenesis was also asynchronous at the individual level, and designed to produce several pulses that appeared to match the several oocyte cohorts noticed in the female individuals. In both years, about $10-43 \%$ of male individuals had spermatic cysts simultaneously with transdifferentiated choanocytes (Figure 4). Although at a population level transdifferentiated choanocytes occured during all the reproductive cycle (April-December, Figure 4), at an individual level these cells tended to disappear within a given individual after the appearance of their spermatic cysts (Figure 7 ). The process of change from transdifferentiated choanocytes to spermatic cyst 3 took at least 5 days. Likewise, the development of cysts was not necessarily a single continuous process within the individuals. Some tagged individuals had two peaks during the annual reproductive cycle (Figure 7), and transdifferentiation of choanocytes appeared to last a month (Figure 7). These observations implied that transdifferentiated choanocytes were produced in pulses.

Assuming that spawning took place shortly after spermatic cysts matured, it can be deduced that reproductive pulses 


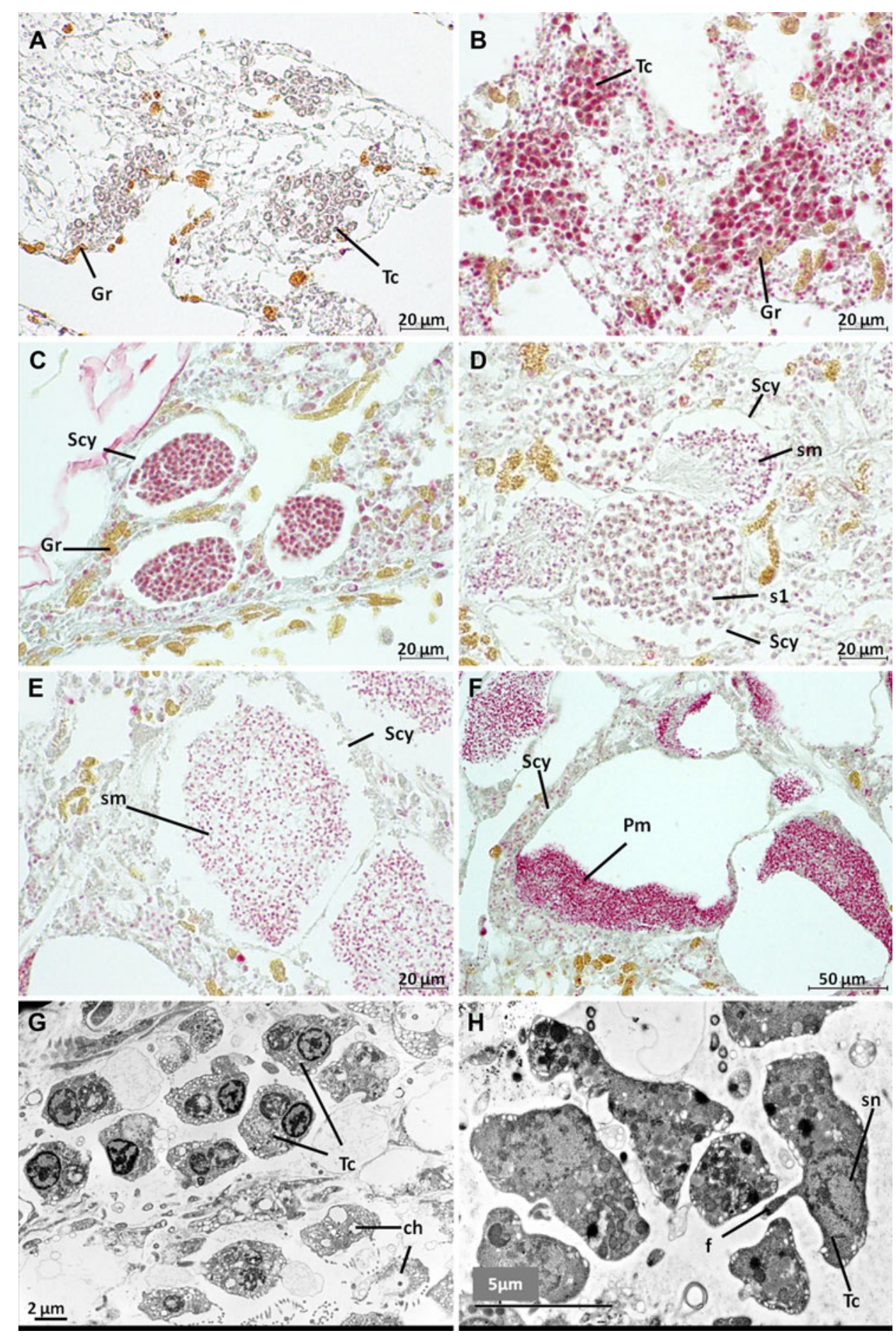

Fig. 6. Spermatogenesis observed by light microscopy and TEM. (A and B) Transdifferentiation of choanocytes into spermatogonia (Tc), in which choanocyte chambers fuse with each other forming groups and interacting with granular cells. (C) Cyst stage 1 (with possible spermatogonia); (D) cyst stage 2 (spermatocytes I) and cyst stage 3 (spermatids or spermatozoa) co-occurring in the same individual; (E) cyst stage 3 (spermatids or spermatozoa); (F) cyst stage 4 (condensed spermatozoa). (G-H) TEM of transdifferentiated choanocytes. ch: choanocyte; f: flagellum; Gr: granulose cell; Pm: spermatozoa; s1: spermatocytes I; Scy: spermatic cyst; sm: spermatids or spermatozoa; sn: synaptonemal complexes; Tc: transdifferentiated choanocytes.

occurred several times during summer, in consecutive months and even twice in the same month (Figures $3 \& 4$ ). In the first year of study (2009-2010) 'mature or nearly mature' spermatic cysts were observed at three different times (Figures 3 \& $4)$, whereas during the second year (2010-2011) they were observed five times (Figures 3 \& 4). Differences between tagged and random individuals were observed; for example, proportions of female and males were different, and the presence of spermatic cysts occurred only simultaneously in tagged and random samples on 20 May 2010, 29 June 2011 and 20 July 2011 (Figure 3). These differences during reproductive peaks, and that not all individuals engage in reproduction at each peak, clearly indicated that the whole population was reproducing asynchronously (Figure 4). However, the 


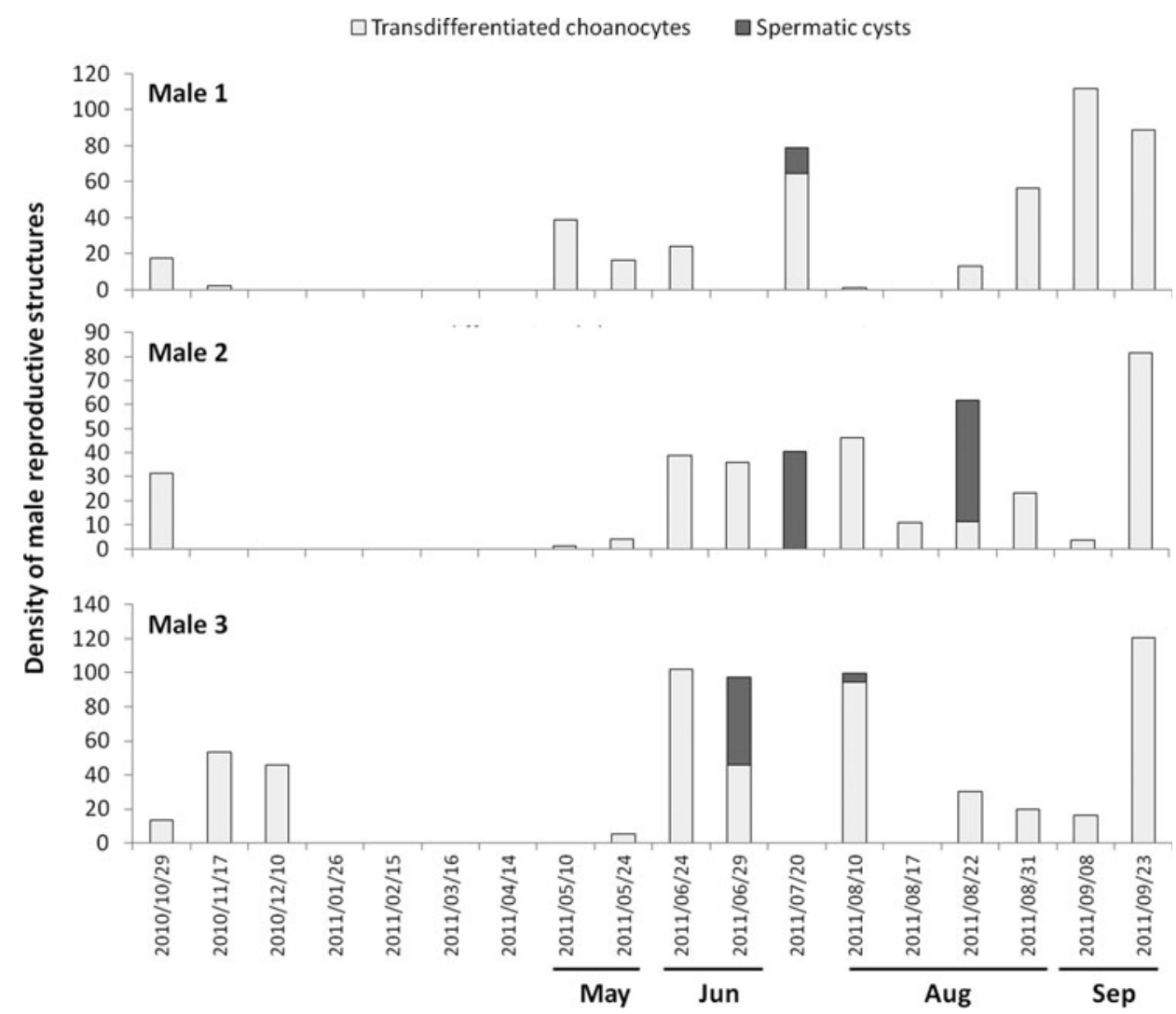

Fig. 7. Density of transdifferentiated choanocytes and spermatic cysts for the tagged sponges that were males $(\mathrm{N}=3)$ in year 2010-2011. The other seven individuals: four were females (Figure 5) and three did not present any reproductive structure.

percentage of mature oocytes (stage IV) was higher (in three of the eight reproductive events) when all observed spermatic cysts were nearly mature (cyst 3) or mature (cyst 4) (Figure 8). This correlation indicated that pulses of oogenesis and spermatogenesis were coupled, with subpopulations of males and females having the maturation of at least part of their gametes synchronized for spawning and successful fertilization. These synchronized spawning pulses occasionally occurred twice a month, as was the case in August 2010 and June 2011 (Figure 8). Although spermatic cysts were used to indicate possible spawning events, coupled events with mature female and male reproductive structures were fewer (see Figure 8). This means that spermatic cysts and oocytes in other events were not mature at the time of sampling, but they were present and probably reached maturity later. It is important to consider that we did not sample all the population, and that other individuals not included in this study may also be contributing to each spawning event.

\section{Relation to environmental variables}

Both percentage of individuals with reproductive structures and density of reproductive structures were higher during the warmer months of the year (Figures $3 \& 4$ ). Mean density (per sampling date) of reproductive structures increased with increasing seawater temperature, although the strength of such a statistical association was only moderate (oocytes: Pearson $r=0.4, N=41, P<0.05$, including random and tagged females both years, and Pearson $r=0.7, N=12, P<$ 0.05 , only including tagged females from second year; transdifferentiated choanocytes: Spearman $r=0.7, N=41, P$ $<0.05$, including random and tagged males both years, and Pearson $r=0.6, N=12, P<0.05$, only including tagged males from second year). However, during the colder months of the year, December to April for 2009-2010, and January to March for 2010-2011, oocytes remained in stages I and II. The winter of 2009-2010 was longer than that of the second year, with a 1 month delay for water temperature to reach the $25^{\circ} \mathrm{C}$ threshold, and for oocytes to start stage III of development (i.e. $25^{\circ} \mathrm{C}$ was reached at the end of May in 2010 and middle of April in 2011). Similarly, choanocytes started transdifferentiation (to form spermatic cells) exactly at the same time that oocytes started stage III of development. Thus, water temperature above $25^{\circ} \mathrm{C}$ appears to trigger the maturation of oocyte cohorts (before and after winter) and it also stimulates the transdifferentiation of choanocytes into spermatogonia.

Based on the presence of spermatic cysts, three possible spawning events were detected for 2010, and five for 2011 . All of them occurred during summer, 2-8 days before or after full and new moons (Figure 9). Two spawning events a month appeared to occur in August 2010, concurrent with two full moons, and also in June 2001, but this time concurrent with a full and a new moons (June 2011). In August 2011 only spermatic cysts in early development were registered (cysts 1 and 2), suggesting two spawning events that may possibly occur slightly later, probably during or after August full and new moons (Figure 9). Spawning of gametes was not fully synchronized with moon phases for all reproductive events. However, three of the eight events in which 
2010

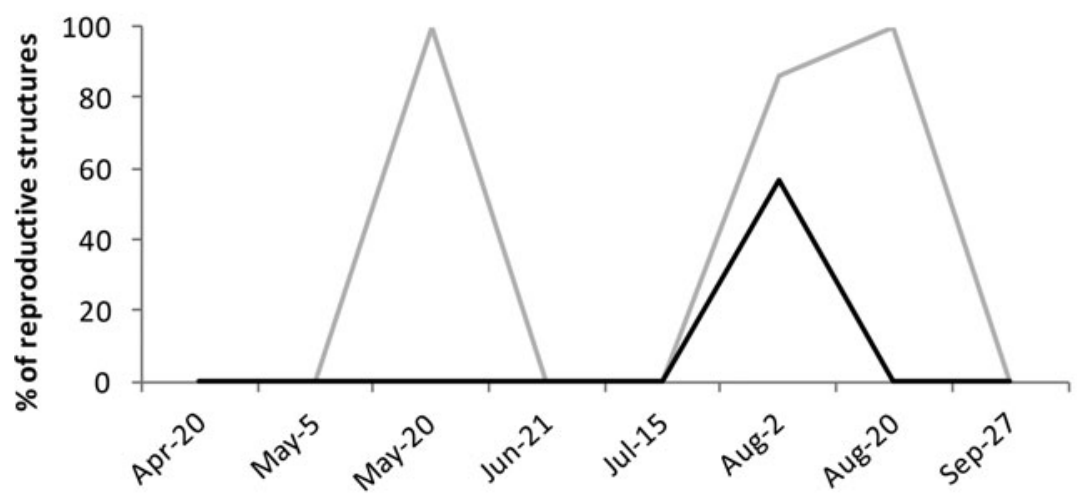

2011

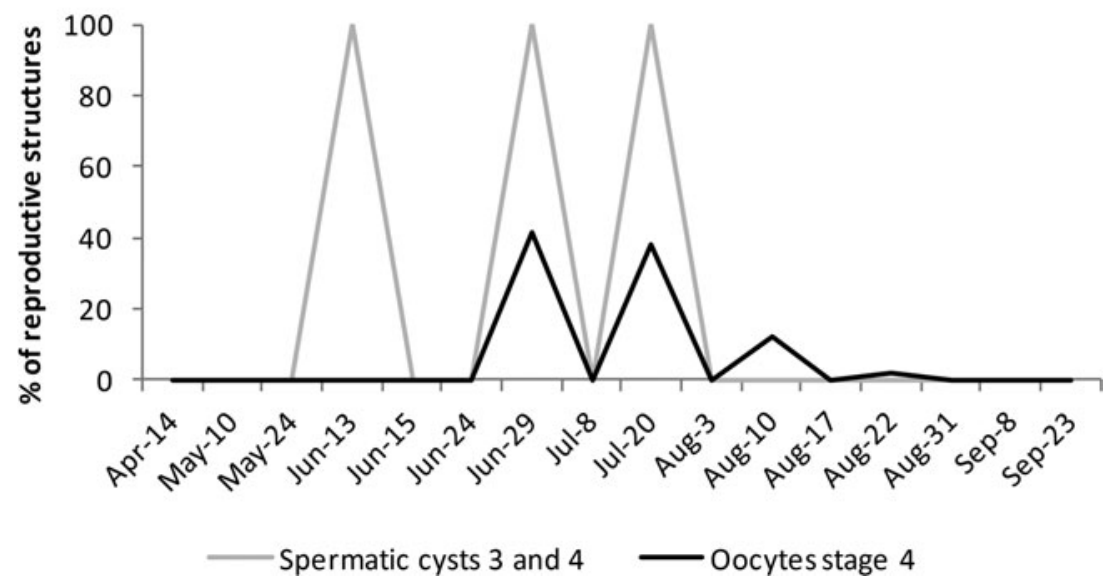

Fig. 8. Percentage of mature reproductive structures (only spermatic cysts 3 and 4 and oocytes stage IV) for summer 2010 (upper graph) and summer 2011 (lower graph). Asynchrony at population level was evident, with subpopulations of females (oocytes) and males (spermatic cysts) matching for some spawning events (all spawning events based only on the presence of spermatic cysts are shown in Figure 9). Spermatic cysts in August 2011 are not shown, as they were cysts in stage 1 and 2 .

spermatic cysts were registered, occurred 3-4 days before the full moon, and one more, 2 days before a new moon. Considering the reproductive asynchrony characterizing $C$. delitrix, it is possible that both full and new moons trigger the spawning, and that only those individuals with gametes near maturation at those given times participate in the spawning.

\section{Sexuality and sex ratio}

Most C. delitrix individuals were either male or females (gonochoric), and sex reversal was never observed in the marked individuals. Out of 650 individuals examined, only three were corroborated to be simultaneous hermaphrodites: one with spermatic cysts at stage 2, transdifferentiated choanocytes (early sperm cells), and oocytes at stage II as well; the other two had both transdifferentiated choanocytes (early sperm cells) and early oocytes (stage I). The weekly analysis in August showed 2.9\% of individuals were hermaphrodites with oocytes and transdifferentiated choanocytes occurring simultaneously. These data support that $C$. delitrix is essentially a gonochoric species, but a small percentage of hermaphroditic individuals occurs in the population (Figure 4). The estimated sex ratio varied at each reproductive pulse, and was closer to parity when both spermatic cysts and transdifferentiated choanocytes were used to assign males (Table 2). It departed from parity when only spermatic cysts were used to assign males; in this case females were more frequent during most reproductive peaks (Table 2).

\section{DISCUSSION}

Cliona delitrix is an oviparous, gonochoric sponge (rare hermaphrodite individuals can occur), with multiple spawning events per year concentrated in the warmest months (water temperature $>25^{\circ} \mathrm{C}$ ). In this species the female gametogenesis is longer than the male one, and asynchrony at the individual and at the local population level occurs. However, synchronized pulses of gametogenesis in male and female subpopulations can happen for coupled spawning events. This study is the first report of the reproductive cycle in C. delitrix and presents the first description of transdifferentiated choanocytes into spermatic cells and the use of these cells to estimate female:male ratio and length of the reproductive period for the genus Cliona.

Like other members of the genus Cliona, C. delitrix appears to be oviparous (Piscitelli et al., 2011; Bautista-Guerrero et al., 

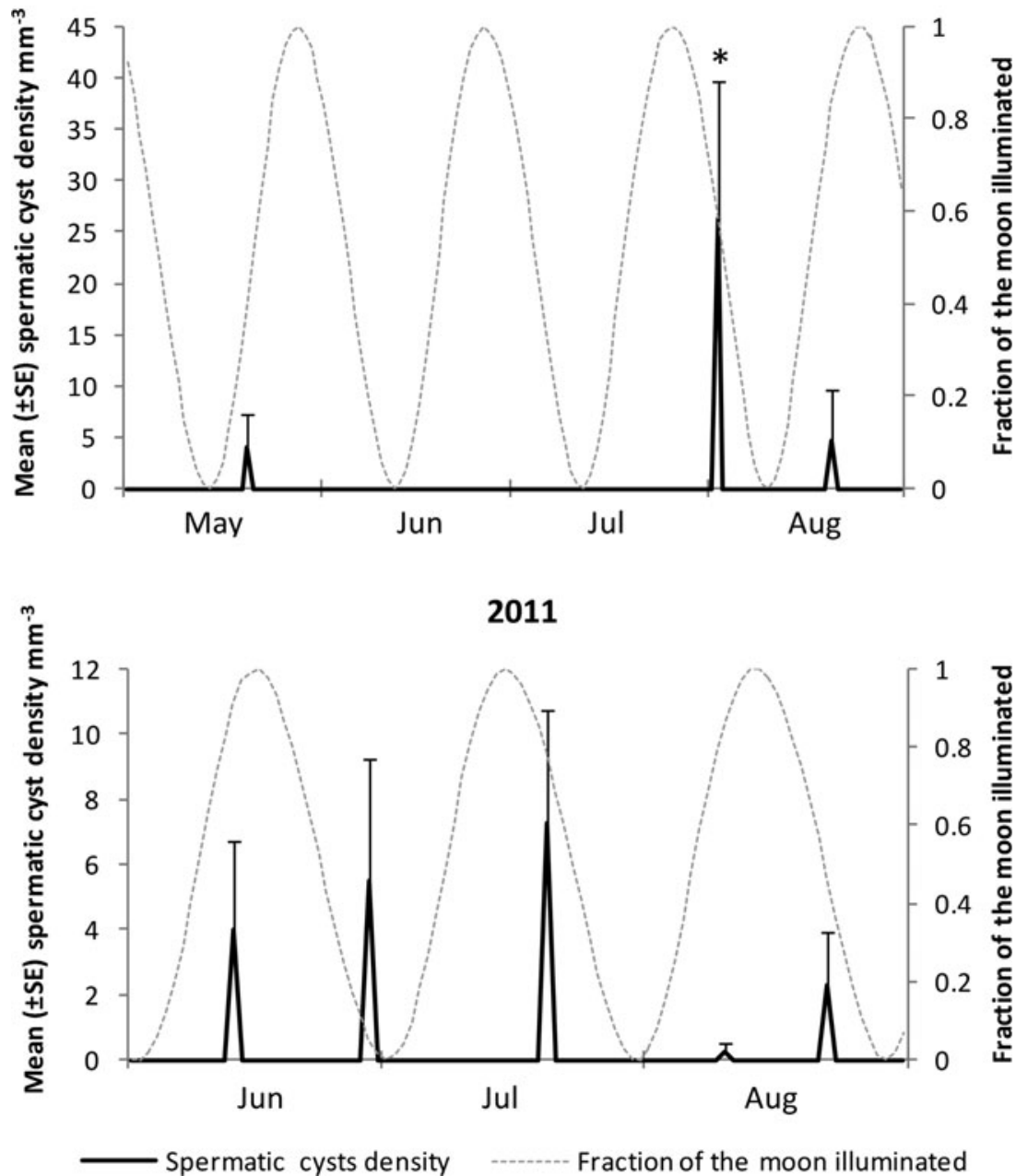

Fig. 9. Density $( \pm S E)$ of spermatic cysts (all stages) in relation to moon phases for summer 2010 and 2011. Fraction of the moon illuminated is shown as harmonic oscillation waves over time; full moon (peaks) and new moon (valleys). (*): closest date to a spawning 2 August 2010: density of spermatic cysts was higher, and only date in which cysts 4 were registered.

Table 2. Ratio of female to male individuals at each reproductive peak combining tagged and randomly sampled individuals. Females and males were assigned depending on the presence of only $\mathrm{O}$ : oocytes and SC: spermatic cysts, and also for males adding both SC and Tc: transdifferentiated choanocytes. Hermaphrodites were not included in the analysis.

\begin{tabular}{llllll}
\hline Date & \multicolumn{1}{l}{$(\mathrm{O}: \mathrm{SC})$} & & \multicolumn{2}{l}{$(\mathrm{O}: \mathrm{SC}+\mathrm{Tc})$} \\
\cline { 2 - 3 } \cline { 5 - 6 } (reproductive peak) & $\begin{array}{l}\text { Female }: \\
\text { Male }\end{array}$ & $\begin{array}{l}\mathbf{N} \\
(\boldsymbol{r}+\boldsymbol{t})\end{array}$ & & $\begin{array}{l}\text { Female }: \\
\text { Male }\end{array}$ & $\begin{array}{l}\mathrm{N} \\
(\boldsymbol{r}+\boldsymbol{t})\end{array}$ \\
\hline 20 May 2010 & $1: 3$ & 7 & & $1: 3$ & 7 \\
2 Aug 2010 & $1: 1$ & 8 & & $1: 1$ & 8 \\
20 Aug 2010 & $3: 1$ & 4 & & $1: 2$ & 8 \\
13 June 2011 & $5: 1$ & 11 & & $3: 1$ & 12 \\
29 June 2011 & $4: 1$ & 10 & & $1: 1$ & 14 \\
20 July 2011 & $1: 2$ & 15 & & $1: 2$ & 15 \\
10 Aug 2011 & $4: 1$ & 10 & & $1: 1$ & 15 \\
22 Aug 2011 & $4: 1$ & 18 & & $1: 1$ & 26 \\
Total & $3: 1$ & 83 & & $1: 1$ & 105 \\
\hline
\end{tabular}

$\mathrm{N}$ : total number of individuals sampled; $r$ : random individuals; $t$ : tagged individuals.
2014). Neither embryos nor larvae were observed in any individual, suggesting that cleavage occurs once zygotes are expelled from the sponges. Thus, embryogenesis seems to occur outside the sponge, while fertilization could occur either externally or internally. In the latter case, the zygotes would be quickly expelled after fertilization for external development, as reported for other clionaids (Maldonado \& Riesgo, 2008; Bautista-Guerrero et al., 2014).

The presence of few hermaphroditic individuals in gonochoric species such as Cliona delitrix is a common strategy in sponges (e.g. Liaci \& Sciscioli, 1967; Fell, 1970; Simpson, 1984; Baldacconi et al., 2007), and is due to genetic and physiological factors, as well as to environmental cues (Simpson, 1984; Ghiselin, 1987; McCartney, 1997; Prevedelli et al., 2006). Hermaphroditism is also favoured in sessile marine organisms, that unlike $C$. delitrix, are not very abundant and display relaxed sperm competition and localized gamete dispersal (McCartney, 1997). Having a low percentage of simultaneous hermaphrodites may favour C. delitrix asynchronous reproductive strategy, helping to equilibrate the ratio of females:males during specific reproductive pulses.

The sex ratio in Cliona delitrix was variable and in most cases departed from parity if only spermatic cysts were used 
to assign males. In this case females were more frequent than males, similar to C. vermifera (Bautista-Guerrero et al., 2014). However, the sex ratio was closer to parity when transdifferentiated choanocytes were also used to assign males. These results suggest that parity may be the norm in this species, and that reproduction in $C$. delitrix would agree with the Düsing-Fisher's sex ratio principle (Queller, 2006). Disparity in sex ratio as observed in other Cliona sponges (González-Rivero et al., 2013; Bautista-Guerrero et al., 2014) may relate to sampling bias, as spermatogenesis is usually very short, and the reproduction rhythm can be missed at times. In this case, using transdifferentiated choanocytes can help to trace male individuals for a couple of days more, and match the reproduction rhythm in the population.

Cliona delitrix oocytes' morphology and size were similar compared with other Cliona spp. We found that oocytes interacted with granular cells (nurse cells) from the beginning of oogenesis. Previous reports of association of granular cells and reproductive elements are restricted to mature oocytes of some Cliona spp. and their larvae (Warburton, 1961; Piscitelli et al., 2011). For males, granular cells were observed interspersed and in continuous interaction with choanocytes transdifferentiating into gametogonia. However granular cells did not enter spermatic cysts at any time, implying that they may only be involved in the process of transdifferentiation of choanocytes into spermatic cells, but not in subsequent stages. The development inside each spermatic cyst was synchronous, as in C. vermifera (Bautista-Guerrero et al., 2014).

The length of the seasonal reproductive cycle of $C$. delitrix overlaps with that of a few other sponges studied in Florida (Maldonado \& Young, 1996; Leong \& Pawlik, 2011). Considering that development of reproductive structures in C. delitrix requires temperatures of $25^{\circ} \mathrm{C}$ and above, we hypothesize that in the tropics reproduction could occur year around. In this case, the opportunity of colonizing new coral colony substratum may be higher, as the sponges would have more spawning events. However, food availability and other environmental factors could limit its reproductive potential (Maldonado \& Riesgo, 2008). Additional studies of sponges from tropical areas will be necessary to test this hypothesis.

Spawning of gametes was not synchronized with moon phases. However, in four of eight reproductive events, spermatic cysts were observed 2-4 days before the full or new moons. Thus, it is possible that to a certain extent moon phases triggered the development and spawning, permitting two spawning events in the same month (i.e. June 2011). The relationship between lunar phases and sponge spawning has been suggested before for some species such as Chondrilla australiensis Carter (1873), which spawns 11 days after the full moon (Usher et al., 2004), and Neofibularia nolitangere Duchassaing \& Michelotti (1864) which starts releasing gametes on the third day after the full moon (Hoppe \& Reichert, 1987).

Although the C. delitrix reproductive cycle is seasonal, it does not follow the typical pattern of seasonal oviparous species of Cliona or Pione, which often have only one or two highly synchronic major spawning events or zygote releases during the warmest season (Pomponi \& Meritt, 1990; Piscitelli et al., 2011; Bautista-Guerrero et al., 2014). In contrast, $C$. delitrix reproduction has more than one reproductive pulse, with possibly several spawning events per year, similar to some viviparous sponges (e.g. Ilan \& Loya, 1990;
Whalan et al., 2007). The percentage of reproductively active $C$. delitrix individuals varies over time, gamete development is asynchronous within the individuals, and production of gametes occurred in discrete periods not synchronized among all the individuals in the population. Therefore, C. delitrix reproduction involves only a fraction of the population at different times during the reproductive period, a characteristic that places this species in the category of asynchronous but year-round reproductive organisms (Gage \& Tyler, 1991; Witte, 1996; Mangubhai \& Harrison, 2008). Indeed, at the population level, oogenesis in C. delitrix occurs as a continuous process over the year; even during the coldest months early stage (I and II) oocytes were observed in few individuals. Maintaining oocytes in the tissue after the reproductive season is a characteristic that has not been reported in other clionaids, as gametic activity typically ceases after the release of eggs or zygotes (Piscitelli et al., 2011; Bautista-Guerrero et al., 2014). This capability could favour $C$. delitrix to engage in reproduction immediately after the environmental conditions are suitable.

Cliona delitrix gamete status and reproductive cycle are both different compared with reproductive cycles of Cliona species from the Mediterranean (water temperature $15-32^{\circ} \mathrm{C}$ ), but similar to species in the Caribbean Sea and the Pacific Ocean $\left(22-32^{\circ} \mathrm{C}\right)$. Mediterranean Sea C. celata and $C$. viridis are hermaphrodites with longer oogenesis and a very rapid spermatogenesis, which leads to one single spawning event in May (Mariani et al., 2000; Piscitelli et al., 2011). The Caribbean species C. delitrix and C. tenuis, and the Pacific species $C$. vermifera are gonochoric (González-Rivero et al., 2013; Bautista-Guerrero et al., 2014). Both C. delitrix and C. vermifera can have more than two pulses of spermatogenesis and more than two cohorts of oogenesis: C. delitrix between April and December and C. vermifera between July and November (Bautista-Guerrero et al., 2014). This scenario has also been suggested, but not documented, for C. tenuis (González-Rivero et al., 2013). Multiple spawning events represent a strategy that increases reproductive success by decreasing the risk of massive offspring mortality in the event of local adverse events (Richmond \& Hunter, 1990). In addition, it can increase the chances of successful colonization, and the likelihood that these species recruit at some point when suitable, unoccupied substratum is available. The three species, $C$. delitrix, $C$. tenuis and C. vermifera, colonize corals (López-Victoria \& Zea, 2005; Chaves-Fonnegra \& Zea, 2011; Bautista-Guerrero et al., 2014), and specifically $C$. delitrix has a preference for massive corals, and recently dead coral where coral skeleton is clean and exposed (Chaves-Fonnegra \& Zea, 2011; Chaves-Fonnegra, 2014), whereas the Mediterranean species C. celata and C. viridis colonize different types of calcareous substrata, including limestone (Volz, 1939; de Groot, 1977; Mariani et al., 2000). It is possible that having more reproductive pulses can enhance changes of recruitment on a substratum more difficult to find, such as recently dead coral skeletons (Carballo et al., 2013; Chaves-Fonnegra, 2014).

The increase of coral bleaching and mortality (HoeghGuldberg, 1999; Gardner et al., 2003; Eakin et al., 2010) provides more suitable substratum for coral-excavating sponges to recruit (Schönberg \& Ortiz, 2008; Carballo et al., 2013; Chaves-Fonnegra, 2014). Therefore, multiple pulses of spawning events over the warmer months of the year are a strategy that helps to guarantee recruitment and avoid competition for 
space (e.g. Whalan et al., 2007; Mangubhai \& Harrison, 2008). Indeed, as sponge spawning is occurring in the same season as thermal stress and mortality in Caribbean corals (Eakin et al., 2010), the possibility of $C$. delitrix larval recruitment on exposed coral skeleton is even higher.

The number of spawning events detected appears to be related to the intensity of sampling effort (number of individual collected, and number of times sampled). For example, in 2009-2010, sampling effort was less than in 2010-2011; as result, the number of spawning events detected were three in the first year, and five in the second. Considering that not all the population reproduces simultaneously, increasing the sampling effort during the reproductive cycle could show more spawning per year for $C$. delitrix.

Overall, the versatile sexual reproduction of $C$. delitrix appears to contribute to its proliferation. Its extended reproductive cycle with multiple spawning events suggests that C. delitrix has a reproductive strategy that reduces the risk of massive offspring mortality during catastrophic events, and it gives it a chance to compete for space with other reef invertebrates (Richmond \& Hunter, 1990; Mangubhai \& Harrison, 2008). Thus, the increase of C. delitrix on coral reefs can be attributed not only to organic contamination by sewage (Rose \& Risk, 1985; Ward-Paige et al., 2005; Chaves-Fonnegra et al., 2007), but also to its multi-spawning reproductive strategy, that combined with its ability to kill coral tissue and excavate coral skeletons - much deeper than most excavating sponges - make of this species a successful reef bioeroder (Pang, 1973; Chaves-Fonnegra \& Zea, $2007,2011)$. In addition, climate change is increasing coral mortality, and is opening more space for this sponge to recruit on corals (Chaves-Fonnegra, 2014). Management and coral restoration alternatives to control $C$. delitrix should address the reduction of sewage waste, and factors that are affecting coral health at a broad scale (i.e. $\mathrm{CO}_{2}$ emissions) (e.g. Hughes et al., 2003; Pandolfi et al., 2003). We recommend including $C$. delitrix in monitoring efforts around the Caribbean Sea and Atlantic, as it is an important bioindicator not only of water quality, but also of coral degradation and bioerosion.

\section{ACKNOWLEDGEMENTS}

These results were presented by A.C.-F. as part of her PhD dissertation in NOVA Southeastern University, Oceanographic Center, Florida, USA. Fieldwork was possible thanks to the NSU Diving Program, L. Robinson, D. Gilliam, K. O’Neil and members of the NSU Coral Reef Restoration and Monitoring Laboratory (CRRAM). Laboratory work was supported by A. Renegar and members of the NSU Coral Histology and Marine Microbiology and Genetics Laboratories. Special thanks to S. Zea and B. Riegl for suggestions on methods and analyses, and to $\mathrm{S}$. Zea for C. delitrix photographs.

\section{FINANCIAL SUPPORT}

This work was funded through the UNESCO-L'Oréal Fellowship for Young Women in Science, the $\mathrm{PhD}$ scholarship program from Colombian Science and Technology Department (COLCIENCIAS), Billfish Tournament Scholarship, the Broward Women Association Scholarship, and the President's
Faculty Research and Development Grant to JVL and AC-F by Nova Southeastern University.

\section{REFERENCES}

Baldacconi R., Nonnis-Marzano C., Gaino E. and Corriero G. (2007) Sexual reproduction, larval development and release in Spongia officinalis L. (Porifera, Demospongiae) from the Apulian coast. Marine Biology 152, 969-979.

Banks K.E., Riegl B.M., Richards V.P., Walker B.E., Helmle K.P. and Jordan L.K.B. (2008) The reef tract of continental Southeast Florida (Miami-Dade, Broward, and Palm Beach Counties, USA). In Riegl B. and Dodge R.E. (eds) Coral reefs of the USA. New York, NY: Springer-Verlag, pp. 175-220.

Bautista-Guerrero E., Carballo J.L. and Maldonado M. (2014) Abundance and reproductive patterns of the excavating sponge Cliona vermifera: a threat to Pacific coral reefs? Coral Reefs 33, 259-266.

Carballo J.L., Bautista E., Nava H., Cruz-Barraza J.A. and Chavez J.A. (2013) Boring sponges, an increasing threat for coral reefs affected by bleaching events. Ecology and Evolution 3, 872-886.

Carter H.J. (1873) On two new species of Gummineae, with special and general observations. Annals and Magazine of Natural History 12, 17-30, pl. I.

Chaves-Fonnegra A. (2014) Increase of excavating sponges on Caribbean coral reefs: reproduction, dispersal and coral deterioration. Doctoral dissertation. Nova Southeastern University, Dania Beach, 195 pp.

Chaves-Fonnegra A., Feldheim K.A., Secord J. and Lopez J.V. (2015) Population structure and dispersal of the coral-excavating sponge Cliona delitrix. Molecular Ecology 24, 1447-1466.

Chaves-Fonnegra A. and Zea S. (2007) Observations on reef coral undermining by the Caribbean excavating sponge Cliona delitrix (Demospongiae, Hadromerida). In Custódio M.R., Lôbo-Hajdu G., Hajdu E. and Muricy G. (eds) Porifera research: biodiversity, innovation and sustainability. Rio de Janeiro: Museu Nacional, pp. 247-254.

Chaves-Fonnegra A. and Zea S. (2011) Coral colonization by the encrusting excavating Caribbean sponge Cliona delitrix. Marine Ecology 32, $162-173$.

Chaves-Fonnegra A., Zea S. and Gómez M.L. (2007) Abundance of the excavating sponge Cliona delitrix in relation to sewage discharge at San Andrés Island, SW Caribbean, Colombia. Boletín de Investigaciones Marinas y Costeras 36, 63-78.

Cortés J., Murillo M., Guzmán H.M. and Acuña J. (1984) Pérdida de zooxantelas y muerte de corales y otros organismos arrecifales en el Caribe y Pacífico de Costa Rica. Revista de Biología Tropical 32, 227-231.

de Groot R.A. (1977) Boring sponges (Clionidae) and their trace fossils from the coast near Rovinj (Yugoslavia). Geologie en Mijnbouw 56, $168-181$.

Duchassaing De Fonbressin P. and Michelotti G. (1864) Spongiaires de la mer Caraibe. Natuurkundige verhandelingen van de Hollandsche maatschappij der wetenschappen te Haarlem 21, 1-124, pls I-XXV.

Duckworth A.R. and Peterson B.J. (2013) Effects of seawater temperature and $\mathrm{pH}$ on the boring rates of the sponge Cliona celata in scallop shells. Marine Biology 160, 27-35.

Eakin C.M., Morgan J.A., Heron S.F., et al. (2010) Caribbean corals in crisis: record thermal stress, bleaching, and mortality in 2005. PLoS ONE 5, 1-9.

Enochs I.C., Manzello D.P., Carton R.D., Graham D.M., Ruzicka R. and Collela M.A. (2015) Ocean acidification enhances the bioerosion of a common coral reef sponge: implications for the persistence of the 
Florida Reef Tract. Bulletin of Marine Science 91, doi: 10.5343/ bms.2014.1045 2015.

Fang J.H.K., Athayde M.A.M., Schönberg C.H.L., Kline D.I., Hoegh-Guldberg O. and Dove S. (2013) Sponge biomass and bioerosion rates under ocean warming and acidification. Global Change Biology 19, 3581-3591.

Fell P.E. (1970) The natural history of Haliclona ecbasis de Laubenfels, a siliceous sponge of California. Pacific Science Journal 24, 381-386.

Gage J.D. and Tyler P.A. (1991) Deep-sea biology: a natural history of organisms at the deep sea floor. Cambridge: Cambridge University Press, pp. 524.

Gardner T.A., I.M. C., Gill J.A., Grant A. and Watkinson A.R. (2003) Long-term region-wide declines in Caribbean corals. Science 301, 958-960.

Ghiselin M.T. (1987) Evolutionary aspects of marine invertebrate reproduction. In Giese C.A., Pearse J.S. and Pearse V.B. (eds) Reproduction of marine invertebrates. Palo Alto, CA: Blackwell Scientific, pp. 609666.

Gilliam D.S. (2012) Southeast Florida coral reef evaluation and monitoring project 2011. Year 9 Final Report. Florida DEP Report \#RMo85 Miami Beach, FL. 49 pp.

González-Rivero M., Ereskovsky A.V., Schönberg C.H.L., Ferrari R., Fromont J. and Mumby P.J. (2013) Life-history traits of a common Caribbean coral-excavating sponge, Cliona tenuis (Porifera: Hadromerida). Journal of Natural History 47, 2815-2834.

Grant R.E. (1826) Notice of a new zoophyte (Cliona celata Gr.) from the Firth of Forth. Edinburgh New Philosophical Journal 1, 78-81.

Hancock A. (1849) On the excavating powers of certain sponges belonging to the genus Cliona with descriptions of several new species, and an allied generic form. Annals and Magazine of Natural History 3, 321348 , pls XII-XV.

Hancock A. (1867) Note on the excavating sponges; with descriptions of four new species. Annals and Magazine of Natural History 19, 229242, pls VII-VIII.

Hoegh-Guldberg O. (1999) Climate change, coral bleaching and the future of the world's coral reefs. Marine and Freshwater Research 50 839-866.

Holmes K.E. (1997) Eutrophication and its effect on bioeroding sponge communities. In Lessios H.A. and Macintyre I.G. (eds) Proceedings of the 8th International Coral Reef Symposium, Panamá, 1997 Smithsonian Tropical Research Institute, pp. 1411-1416.

Hoppe W.F. and Reichert M.J.M. (1987) Predictable annual mass release of gametes by the coral reef sponge Neofibularia nolitangere (Porifera: Demospongiae). Marine Biology 94, 277-285.

Hughes T.P., Baird A.H., Bellwood D.R., Card M., Connolly S.R., Folke C., Grosberg R., Hoegh-Guldberg O., Jackson J.B., Kleypas J., Lough J.M., Marshall P., Nyström M., Palumbi S.R., Pandolfi J.M., Rosen B. and Roughgarden J. (2003) Climate change, human impacts, and the resilience of coral reefs. Science 301, 929-933.

Ilan M. and Loya Y. (1990) Sexual reproduction and settlement of the coral reef sponge Chalinula sp. from the Red Sea. Marine Biology $105,25-31$.

Lang J.C. (2003) Status of coral reefs in the Western Atlantic: results of initial surveys, Atlantic and Gulf Rapid Reef Assessment (AGRRA) Program. Atoll Research Bulletin 496, 1-630.

Leong W. and Pawlik J.R. (2011) Comparison of reproductive patterns among 7 Caribbean sponge species does not reveal a resource trade-off with chemical defenses. Journal of Experimental Marine Biology and Ecology 401, 80-84.
Lévi C. (1956) Etude des Halisarca de Roscoff. Embryologie et systématique des demosponges. Archives de Zoologie Expérimentale et Genérale 93, 1-181.

Liaci L.S. and Sciscioli M. (1967) Osservazioni sulla maturazione sessuale di un tetractinellide: Stelleta grubii O. S. (Porifera). Archivio Zoologico Italiano 52, 169-176.

López-Victoria M. and Zea S. (2005) Current trends of space occupation by encrusting excavating sponges on Colombian coral reefs. Marine Ecology, 26, 33-41.

Maldonado M. (2009) Embryonic development of verongid demosponges supports the independent acquisition of spongin skeletons as an alternative to the siliceous skeleton of sponges. Biological Journal of the Linnean Society 97, 427-447.

Maldonado M. and Bergquist P. (2002) Phylum Porifera. In Young C (ed.) Atlas of marine invertebrate larvae. Barcelona: Academic Press, pp. 21-50.

Maldonado M. and Riesgo A. (2008) Reproduction in the phylum Porifera: a synoptic overview. In Durfort M. and Vidal F. (eds) Biologia de la reproducció, Volume 59. Barcelona: Societat Catalana de Biología, pp. 29-49.

Maldonado M. and Riesgo A. (2009) Gametogenesis, embryogenesis, and larval features of the oviparous sponge Petrosia ficiformis (Haplosclerida, Demospongiae). Marine Biology 156, 2181-2197.

Maldonado M. and Young C. (1996) Effects of physical factors on larval behavior, settlement and recruitment of four tropical demosponges. Marine Ecology Progress Series 138, 169-180.

Mangubhai S. and Harrison P.L. (2008) Asynchronous coral spawning patterns on equatorial reefs in Kenya. Marine Ecology Progress Series $360,85-96$

Mariani S., Uriz M.J. and Turon X. (2000) Larval bloom of the oviparous sponge Cliona viridis: coupling of larval abundance and adult distribution. Marine Biology 137, 783-790.

McCartney M.A. (1997) Sex allocation and male fitness gain in a colonial, hermaphroditic marine invertebrate. Evolution 51, 127-140.

Miller A.W., Blackwelder P.L., Al-Sayegh H. and Richardson L.L. (2011) Fine-structural analysis of black band disease-infected coral reveals boring cyanobacteria and novel bacteria. Diseases of Aquatic Organisms 93, 179-190.

Nassonov N. (1883) Zur biologie und anatomie der Clione. Zeitschrift für Wissenschaftliche Zoologie 39, 295-308.

Old M.C. (1941) The taxonomy and distribution of the boring sponges (Clionidae) along the Atlantic coast of North America. Chesapeake Biological Laboratory Publications 44, 1-30.

Pandolfi J.M., Bradbury R.H., Sala E., Hughes T.P., Bjorndal K.A., Cooke R.G., McArdle D., McClenachan L., Newman M.J., Paredes G., Warner R.R. and Jackson J.B. (2003) Global trajectories of the long-term decline of coral reef ecosystems. Science 301, 955-958.

Pang R.K. (1973) The systematics of some Jamaican excavating sponges (Porifera). Postilla of the Peabody Museum of Natural History at Yale University 161, 1-75.

Piscitelli M., Corriero G., Gaino E. and Uriz M.J. (2011) Reproductive cycles of the sympatric excavating sponges Cliona celata and Cliona viridis in the Mediterranean Sea. Invertebrate Biology 130, 1-10.

Pomponi S.A. and Meritt D.W. (1990) Distribution and life history of the boring sponge Cliona truitti in the Upper Chesapeake Bay. In Rützler K. (ed.) New perspectives in sponge biology. Washington, DC: Smithsonian Institution Press, pp. 384-39o.

Prevedelli D., Massamba n'siala G. and Simonini R. (2006) Gonochorism $v s$. hermaphroditism: relationship between life history and fitness in three species of Ophryotrocha (Polychaeta: 
Dorvilleidae) with different forms of sexuality. Journal of Anima Ecology 75, 203-212.

Queller D.C. (2006) Sex ratios and social evolution. Current Biology 16, R664-R668.

Renegar D.A., Blackwelder P.L., Miller J.D., Gochfeld D.J. and Moulding A.L. (2008) Ultrastructural and histological analysis of dark spot syndrome in Siderastrea siderea and Agaricia agaricites. In Riegl B. (ed.) Proceedings of the 11th International Coral Reef Symposium, Fort Lauderdale, pp. 185-189.

Richmond R.H. and Hunter C.L. (1990) Reproduction and recruitment of corals: comparisons among the Caribbean, the Tropical Pacific, and the Red Sea. Marine Ecology Progress Series 60, 185-203.

Riesgo A. and Maldonado M. (2009) An unexpectedly sophisticated $\mathrm{V}$-shaped spermatozoon in Demospongiae (Porifera): reproductive and evolutionary implications. Biological Journal of the Linnean Society $97,413-426$

Riesgo A., Maldonado M. and Durfort M. (2007) Dynamics of gametogenesis, embryogenesis, and larval release in a Mediterranean homosclerophorid demosponge. Marine and Freshwater Research 58 $398-417$.

Rose C.S. and Risk M.J. (1985) Increase in Cliona delitrix infestation of Montastraea cavernosa heads on an organically polluted portion of the Grand Cayman. Pubblicazioni della Stazione Zoologica di Napoli Marine Ecology 6, 345-363.

Rützler K. (2002) Impact of crustose clionid sponges on Caribbean reef corals. Acta Geologica Hispánica 37, 61-72.

Schmidt O. (1862) Die Spongien des Adriatischen Meeres. Leipzig: Wilhelm Engelmann.

Schönberg C.H.L. (2001) Small-scale distribution of Australian bioeroding sponges in shallow water. Ophelia 55, 39-54.

Schönberg C.H.L. and Ortiz J.-C. (2008) Is sponge bioerosion increasing? Proceedings of the 11th International Coral Reef Symposium, Fort Lauderdale, USA. pp. 520-523.

Simpson T.L. (1984) The cell biology of sponges. New York, NY: Springer-Verlag, pp. 662.

Topsent E. (1900) Etude monographique des spongiaires de France: III. Monaxonides Hadromerina. Archives de Zoologie Expérimentale et Genérale 8, 1-331.
Usher K., Sutton D., Toze S., Kuo S. and Fromont J. (2004) Sexual reproduction in Chondrilla australiensis (Porifera: Demospongia). Marine and Freshwater Research 55, 123-134.

Volz P. (1939) Die Bohrschwämme (Clioniden) der Adria. Thalassia 3, $1-64$.

Warburton F.E. (1961) Inclusion of parental somatic cells in sponge larvae. Nature 191, 1317.

Ward-Paige C.A., Risk M.J., Sherwood O.A. and Jaap W.C. (2005) Clionid sponge surveys on the Florida Reef Tract suggest land-based nutrient inputs. Marine Pollution Bulletin 51, 570-579.

Weil E. (2002) Sponge-induced coral mortality in the Caribbean. A potential new threat to Caribbean coral reefs. In Sarà M., Arillo A. and della Croce N. (eds) Proceedings of the VI Internacional Sponge Conference, Genova,. Canessa, pp. 211-212.

Whalan S., Battershill C. and Nys R.d. (2007) Sexual reproduction of the brooding sponge Rhopaloeides odorabile. Coral Reefs 26, 655-663.

Wisshak M., Schönberg C.H.L., Form A. and Freiwald A. (2012) Ocean acidification accelerates reef bioerosion. PLOS ONE 7, 1-8.

Wisshak M., Schönberg C.H.L., Form A. and Freiwald A. (2014) Sponge bioerosion accelerated by ocean acidification across species and latitudes? Helgoland Marine Research 68, 253-262.

Witte U. (1996) Seasonal reproduction in deep-sea sponges - triggered by vertical particle flux? Marine Biology 124, 571-581.

Zea S. and Weil E. (2003) Taxonomy of the Caribbean excavating sponge species complex Cliona caribbaea - C. aprica - C. langae (Porifera, Hadromerida, Clionaidae). Caribbean Journal of Science 39, 348-370.

and

Zilberberg C., Maldonado M. and Solé-Cava A.M. (2006) Assessment of the relative contribution of asexual propagation in a population of the coral-excavating sponge Cliona delitrix from the Bahamas. Coral Reefs 25, 297-301.

\section{Correspondence should be addressed to:} A. Chaves-Fonnegra NOVA Southeastern University, Oceanographic Center, 8000 North Ocean Drive. Dania Beach, FL, 33004, USA email: andiachaves@gmail.com 